\title{
Article \\ Papain Enzyme Assisted Extraction of Virgin Coconut Oil as Candidate In-House Reference Material
}

\author{
Yulirohyamii *D, Habibi Hidayat, Aprisilia Rizky Wijaya and Is Fatimah (D)
}

Citation: Yulirohyami; Hidayat, $\mathrm{H}$. Wijaya, A.R.; Fatimah, I. Papain Enzyme Assisted Extraction of Virgin Coconut Oil as Candidate In-House Reference Material. Processes 2022, 10, 315. https://doi.org/10.3390/ pr10020315

Academic Editor: Jasna

Čanadanović-Brunet

Received: 21 January 2022

Accepted: 3 February 2022

Published: 6 February 2022

Publisher's Note: MDPI stays neutral with regard to jurisdictional claims in published maps and institutional affiliations.

Copyright: (C) 2022 by the authors. Licensee MDPI, Basel, Switzerland. This article is an open access article distributed under the terms and conditions of the Creative Commons Attribution (CC BY) license (https:// creativecommons.org/licenses/by/ $4.0 /$ )
Chemistry Department, Universitas Islam Indonesia, Kampus Terpadu UII, Jl. Kaliurang Km 14, Sleman, Yogyakarta 55584, Indonesia; habibihidayat13@uii.ac.id (H.H.); aprisilia.risky.wijaya@uii.ac.id (A.R.W.); isfatimah@uii.ac.id (I.F.)

* Correspondence: rohyami@uii.ac.id

\begin{abstract}
This study concerns papain enzyme assisted synthesis of virgin coconut oil (VCO) as a candidate in-house reference material. The study was conducted to obtain optimization of the VCO preparation with green processes as the standardized product which high stability and homogeneity. The method is expected to produce the candidate of in-house reference material to ensure the standards and quality of the VCO product. Based on the results of this study, the preparation of VCO was carried out using the papain. An optimum yield of $24.30 \%$. was achieved under the following conditions: enzyme to coconut milk with a mass ratio of $0.6 \mathrm{~g} / \mathrm{L}$, under $500 \mathrm{~mL}$ water $/ \mathrm{g}$ of coconut powder, at the temperature of $70^{\circ} \mathrm{C}$ by five stages of extraction. The physicochemical properties as well as organoleptic feature of $V C O$ which consist water content, peroxide number, free fatty acids, and iodine numbers are fit with the standard. The parameters exhibited the homogeneity and stability which be able recommended as candidate in-house reference material and have potentially as antibacterial agent. Antibacterial activity test showed that VCO has potential against Escherichia coli, Staphylococcus aureus, Propionibacterium acnes and Pseudomonas aeruginosa as shown by the inhibition zone in the testing.
\end{abstract}

Keywords: papain enzyme; coconut oil; antibacterial agent

\section{Introduction}

Referring to the huge potencies of coconut trees in southeast Asian countries, coconut and its products are the most important commodities for many industrial sectors. As it consists of about 11.95 million hectares producing 57,510 million coconuts annually in the world [1], coconut products have excellent prospects to be developed. One of these prospects is virgin coconut oil (VCO), which has potential for many foods and health industries. VCO has also proven to have biological activities for medical purposes such as antibacterial, antifungal, antioxidant, hepatoprotective, and antiviral activities, and could enhance the immune system. Moreover, these features have been adopted for many health care, cosmetics product, and functional food applications [1-3].

The extraction becomes an essential step for VCO industrialization, which is mainly classified into the traditional boiling method, fermentation, the enzymatic, wet, and dry methods [4]. Such methods in the wet classification are enzymatic-assisted extraction, salted method, fermentation, chilling, freezing, and thawing method [5]. In a more sophisticated technique, supercritical fluid extraction could also be conducted. In different schemes, the dry method utilized could control heating to remove the moister. The combination of both wet and dry methods can also be conducted [6].

The extraction utilizing enzyme was notified as an efficient and green process as the usage of chemicals and energy can be minimized $[7,8]$. As coconut milk consists of complex carbohydrate molecules and protein, the enzyme separates the VCO by binding with oil and amino acid. The functional group of-SH release proteins through the hydrolysis reaction of peptide bonds. Among some enzymes capable of VCO extraction, the papain enzyme 
has considerable potency since it can be produced via many sources such as papaya leaf and fruit [9], and the use of papain enzyme will be an alternative green process for the preparation of $V C O$. The characteristics of $V C O$ as high extraction yield, less water content, low in free fatty acid, and acceptable flavor via the organoleptic test for color and flavor are essential for further application and development on an industrial scale. Based on these backgrounds, this study examined the optimization for $V C O$ extraction by using the papain enzyme. A study on the effect of enzyme ratio, the temperature of coconut milk extraction, and the extraction stage was essential to be designed. In addition, the characteristics of antibacterial activity and homogeneity of the product were the concerns for the applicability as in-house reference material.

\section{Materials and Methods}

\subsection{Materials}

Coconuts were obtained from a cultivation area in Bantul District, Yogyakarta Province, Indonesia. The average weight of the coconuts ranged from 300 to $500 \mathrm{~g}$ each. Some chemicals such as ethanol, phenolphthalein, sodium hydroxide, chloroform, acetic acid, hydrochloride acid, potassium iodide, sodium thiosulfate, starch, cyclohexane, iodine, calcium hypochlorite, peptone, sodium chloride, dipotassium hydrogen phosphate, potassium dihydrogen phosphate, casein, glucose, and filter paper were purchased from Merck-Millipore (Darmstadt, Germany). Papain enzyme was collected from Chem Mix Pratama industry (Indonesia) with the activity of $100,000 \mathrm{u} / \mathrm{g}$.

\subsection{Extraction of VCO}

The papain enzyme was varied at the weight of $0.2 ; 0.4 ; 0.6 ; 0.8$; and $1.0 \mathrm{~g}$ diluted into $10 \mathrm{~mL}$ of phosphate buffer ( $\mathrm{pH}$ 7) followed by homogenization for $1 \mathrm{~h}$ at $4{ }^{\circ} \mathrm{C}$. The mixture was then centrifuged at $1500 \mathrm{rpm}$ for $20 \mathrm{~min}$. The clear supernatant was utilized as VCO extraction. The varied papain concentration was referred to in the literature [10-12].

The VCO extraction was conducted by adding of papain enzyme with varied concentrations with respect to the volume of the coconut milk. The coconut milk was prepared by extracting $1000 \mathrm{~g}$ coconut with $500 \mathrm{~mL}$ of water at the temperature of $50^{\circ} \mathrm{C}$ for $1 \mathrm{~h}$. Figure 1 represents the schematic procedure for $V C O$ extraction.

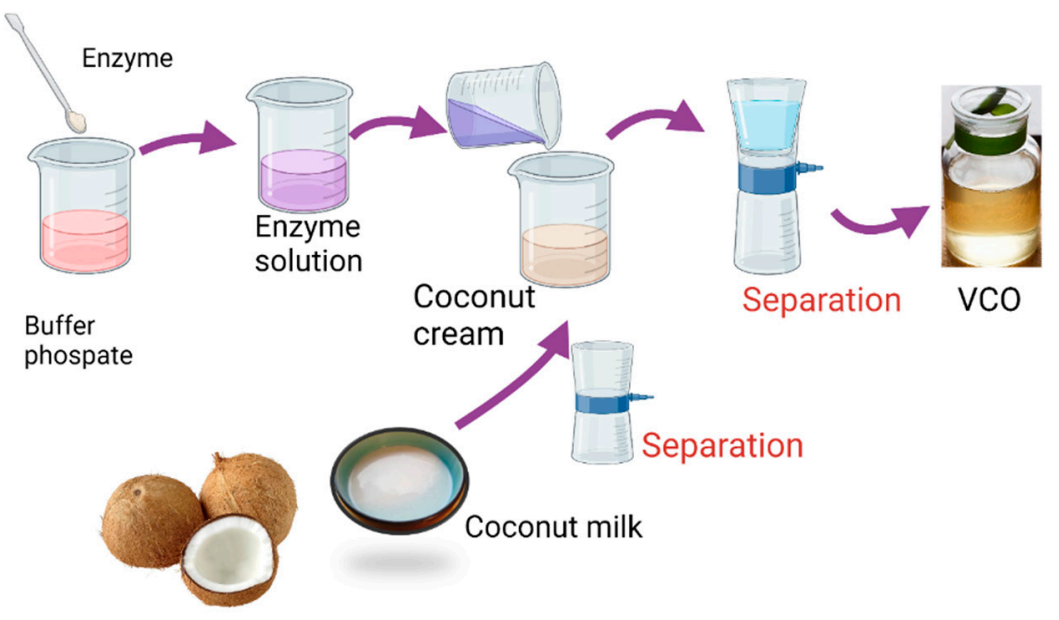

Figure 1. Preparation procedure of virgin coconut oil using papain.

The yield (\%) of VCO extraction was calculated based on gravimetric analysis referred to the following equation:

$$
\text { Yield }(\%)=\frac{m_{V C O}}{m_{C}} \times 100 \%
$$

with $m_{V C O}$ is the mass of $V C O(\mathrm{~g})$, and $m_{C}$ is the mass of coconut milk (g). 
To optimize the yield, the effect of such extraction variables of the volume of water for a gram of coconut milk extraction $(\mathrm{mL} / \mathrm{g})$, papain concentration of $0.3 \mathrm{~g} / 500 \mathrm{~mL}$ was utilized for the first extraction stage.

\subsection{Physicochemical Analyses of VCO}

Determination of physicochemical properties of $V C O$ consists of the analyses of water content, free fatty acid, iodine number, peroxide number, and microbial contamination refer to the standard method of SNI 7381:2008. The determination of water content was measured by gravimetric analysis based on the ashing method. Meanwhile the free fatty acid determination was conducted by alkalimetric on $\mathrm{KOH}$ as the standard solution. The peroxide value was examined by the iodometric titration method using sodium thiosulfate solution as a standard.

\subsection{Antibacterial Activity of VCO}

Antibacterial activity of produced VCO was performed against Escherichia coli, Staphylococcus aureus, Propionibacterium acnes, and Pseudomonas aeruginosa. The antibacterial activity testing refers to previous references [2]. For bacterial growth, a nutrient medium was used. The media was prepared by suspending nutrient agar in distilled water and autoclaved before use. Bacterial culture was evenly spread throughout the Petri plate and a $6 \mathrm{~mm}$ sterile filter disc loaded with $5 \mu \mathrm{L}$ of the $V C O$ from twice dilution factor from the stock solution. As a positive control, ampicillin was used. Meanwhile, dimethyl sulphoxide was utilized as the negative control.

\subsection{Homogeneity Test}

The VCO homogeneity was tested by evaluating the free fatty acid, peroxide, and iodine numbers parameters of kept samples for one to six months. The VCO homogeneity testing refers to previous references [3].

\section{Results and Discussion}

\subsection{VCO Extraction}

The effect of enzyme concentration on the effectiveness of extraction was studied at different ratios of $0.2 ; 0.4 ; 0.6 ; 0.8$; and $1.0 \mathrm{~g} / \mathrm{L}$. As can be seen from the plot in Figure 2, it is seen that the optimum ratio was $0.6 \mathrm{~g} / \mathrm{L}$ which expressed a yield of $20 \%$. Even though enzyme function is as a catalyst for separating oil from water emulsion, the capability of the enzyme to bind with protein reaches an optimum condition that is influenced by many factors. One of these is the ratio or concentration of the enzyme in the extraction system. A similar pattern was also reported by the enzyme-assisted extraction of apricot oil by Pectazyme and Mashzyme enzyme [13]. In addition, the yield results from this work are higher compared to the extraction yields reported before by using seed of papaya [14], papaya latex [11], bromelain [15], and Saccharomyces cerevisiae [16]. With a similar extractant concentration, the yield produced using bromelain was about $12.1 \%$, papaya latex gave about $15 \%$, and about $12.4 \%$ by Saccharomyces cerevisiae.

Mainly, from the varied papain concentration, it is conclusively determined that the concentration of $0.6 \mathrm{~g} / \mathrm{L}$ was the optimum concentration. The greater enzyme concentration than the optimum point tends to convert protein into amino acids producing dark color from the sugar reduction in coconut milk. Besides this, other parameters such as aroma and appearance will be influenced by the protein denaturation in the extraction system [13].

The water volume effect on yield can be seen from the plot in Figure $2 b$. It is seen that $500 \mathrm{~mL} / \mathrm{g}$ of water was the optimum point to give a maximum yield of about $25 \%$. The yield increases until the volume of $500 \mathrm{~mL} / \mathrm{g}$, but then at the additional amount of water, the yield decreases. These data suggest that water participates in giving dilution factor to the enzyme supernatant in the extraction system. Still, in contrast, more water will reduce enzyme productivity as less interaction between protein-papain will occur [17]. Similar to the effect of water volume, the temperature of the extraction and extraction stage for pro- 
ducing coconut milk are the influencing factors [18]. The plots in Figure $2 b, c$ represent the increasing yield at the increasing temperature within the range of room temperature- $50{ }^{\circ} \mathrm{C}$, so the extraction stage is affected until the 5th stage. Even though from the experiment the trend of yield was increasing along with the elevated temperature, theoretically, temperature affected the colloid stability of coconut milk. Such fast protein denaturation will affect the enzyme-coconut milk interaction [17]. The previous investigation determined that protein in coconut milk could be denatured and coagulated at the temperature of $80^{\circ} \mathrm{C}$ and higher. Meanwhile it plays an essential role in the stability of the emulsion [19]. Notably, the extraction stage does not influence the yield representing a stable extraction capability of the enzyme at the varied condition of coconut cream to be treated.
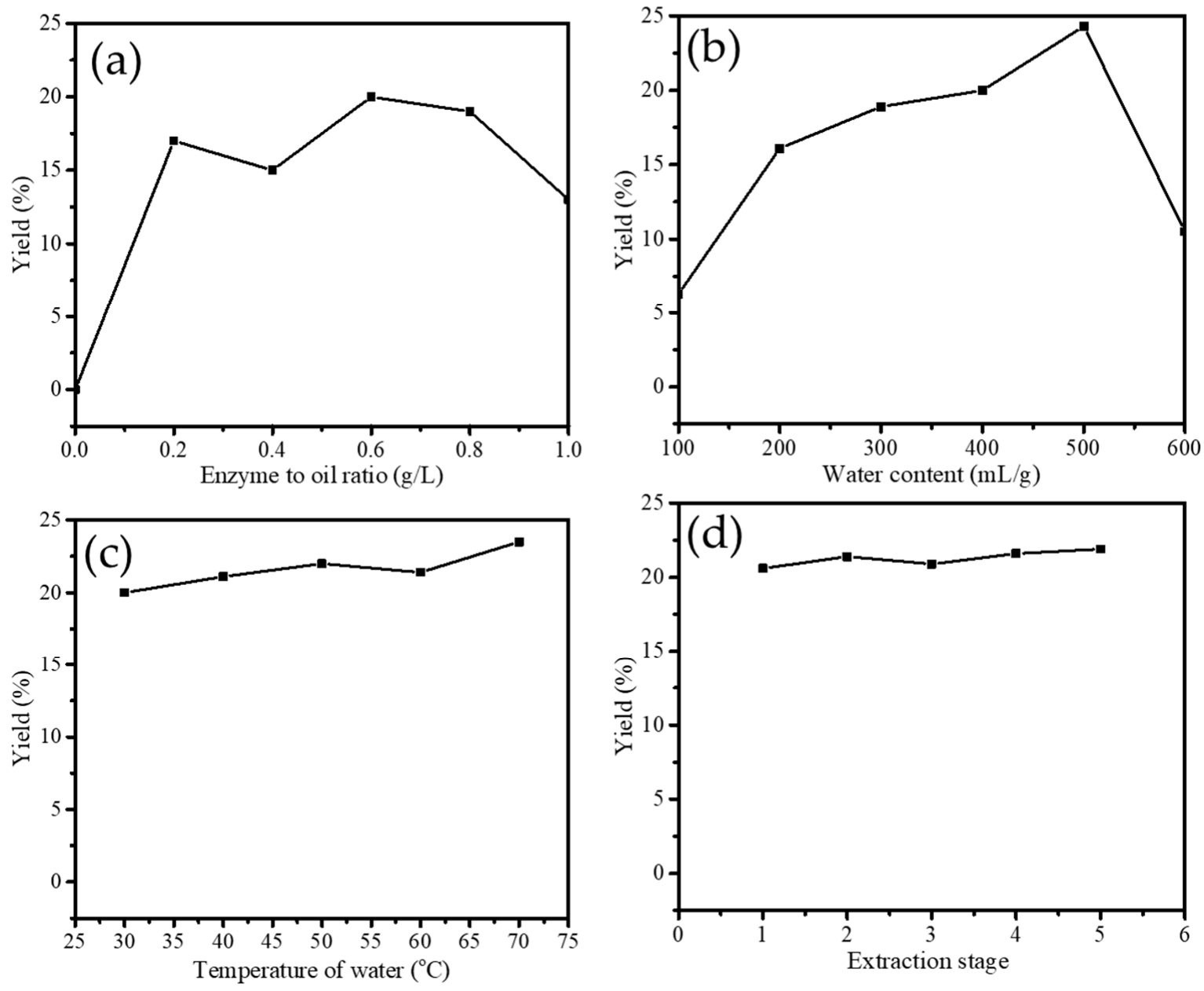

Figure 2. (a). Effect of enzyme on yield of $V C O$ extraction (b). Effect of water content on yield of $V C O$ extraction (c). Effect of temperature of water on yield of $V C O$ extraction (d). Effect of extraction stage on yield of $V C O$ extraction.

The effect of those factors on the VCO quality was studied by water content, FFA content, peroxide value, and iodine numbers examination of the products, as presented in Table 1.

Water content and free fatty acid represent the quality of oil and are related to its stability during preservation, in that a higher water content and FFA value cause the instability of oil. Excess water in the oil accelerates hydrolysis reactions that contributes to the formation of free fatty acids and, moreover, the oxidized free fatty acids will cause rancidity in VCO $[20,21]$. In addition, high-level water content contributes to the bacterial contamination that can hydrolyze oil. From the values in Table 1, it is concluded that all parameters met with the Indonesian standard of VCO refer to SNI 01-3555-1998. Referred 
to the SNI standard, the maximum values of water content, peroxide, and iodine numbers are $<0.2 \%,<0.2 \mathrm{meq} / \mathrm{kg}$, and $4.10-11.00 \mathrm{~g}$ iod $/ \mathrm{kg}$, respectively. This research's yield data is higher than obtained from other similar works, with comparable parameters values as tabulated in Table 2.

Table 1. Physicochemical properties of virgin coconut oil on variation mass of papain.

\begin{tabular}{|c|c|c|c|c|c|}
\hline Factor & Value & Water Content (\%) & $\begin{array}{l}\text { Free Fatty Acid } \\
(\%)\end{array}$ & $\begin{array}{l}\text { Peroxide Number } \\
\quad(\mathrm{meq} / \mathrm{kg})\end{array}$ & $\begin{array}{l}\text { Iodine Number } \\
\text { (g iodine } / 100 \mathrm{~g} \text { ) }\end{array}$ \\
\hline \multirow{6}{*}{$\begin{array}{l}\text { Enzyme to Oil ratio } \\
(\mathrm{g} / \mathrm{L})\end{array}$} & 0 & $0.99 \pm 0.12$ & $0.24 \pm 0.01$ & $0.20 \pm 0.01$ & $7.36 \pm 0.04$ \\
\hline & 0.2 & $1.01 \pm 0.12$ & $0.26 \pm 0.03$ & $0.20 \pm 0.01$ & $8.13 \pm 0.04$ \\
\hline & 0.4 & $1.01 \pm 0.12$ & $0.30 \pm 0.03$ & $0.20 \pm 0.01$ & $8.36 \pm 0.06$ \\
\hline & 0.6 & $1.01 \pm 0.12$ & $0.30 \pm 0.04$ & $0.20 \pm 0.01$ & $8.17 \pm 0.01$ \\
\hline & 0.8 & $1.01 \pm 0.12$ & $0.24 \pm 0.01$ & $0.20 \pm 0.01$ & $8.45 \pm 0.02$ \\
\hline & 1.0 & $1.02 \pm 0.12$ & $0.28 \pm 0.01$ & $0.20 \pm 0.01$ & $8.22 \pm 0.09$ \\
\hline \multirow{6}{*}{$\begin{array}{l}\text { Volume of water } \\
(\mathrm{L} / \mathrm{g})\end{array}$} & 100 & $1.01 \pm 0.22$ & $0.23 \pm 0.01$ & $0.36 \pm 0.16$ & $7.55 \pm 0.01$ \\
\hline & 200 & $1.01 \pm 0.24$ & $0.31 \pm 0.09$ & $0.18 \pm 0.01$ & $7.73 \pm 0.01$ \\
\hline & 300 & $1.01 \pm 0.21$ & $0.31 \pm 0.18$ & $0.18 \pm 0.01$ & $7.91 \pm 0.05$ \\
\hline & 400 & $1.01 \pm 0.23$ & $0.35 \pm 0.06$ & $0.18 \pm 0.01$ & $7.72 \pm 0.03$ \\
\hline & 500 & $1.01 \pm 0.18$ & $0.38 \pm 0.12$ & $0.18 \pm 0.01$ & $7.49 \pm 0.02$ \\
\hline & 600 & $1.01 \pm 0.20$ & $0.42 \pm 0.08$ & $0.18 \pm 0.01$ & $7.51 \pm 0.01$ \\
\hline \multirow{5}{*}{ Tempeature of water $\left({ }^{\circ} \mathrm{C}\right)$} & 30 & $1.00 \pm 0.12$ & $0.31 \pm 0.02$ & $0.18 \pm 0.01$ & $8.26 \pm 1.02$ \\
\hline & 40 & $1.00 \pm 0.13$ & $0.27 \pm 0.05$ & $0.18 \pm 0.01$ & $8.21 \pm 1.66$ \\
\hline & 50 & $1.00 \pm 0.12$ & $0.35 \pm 0.06$ & $0.18 \pm 0.01$ & $8.07 \pm 1.78$ \\
\hline & 60 & $1.00 \pm 0.12$ & $0.27 \pm 0.05$ & $0.18 \pm 0.01$ & $8.33 \pm 0.30$ \\
\hline & 70 & $0.99 \pm 0.13$ & $0.19 \pm 0.04$ & $0.18 \pm 0.01$ & $8.23 \pm 0.97$ \\
\hline \multirow{5}{*}{ Extraction stage } & 1 & $0.99 \pm 0.13$ & $0.35 \pm 0.06$ & $0.18 \pm 0.01$ & $8.23 \pm 0.01$ \\
\hline & 2 & $1.00 \pm 0.12$ & $0.38 \pm 0.12$ & $0.18 \pm 0.01$ & $7.65 \pm 0.04$ \\
\hline & 3 & $0.96 \pm 0.14$ & $0.27 \pm 0.05$ & $0.18 \pm 0.01$ & $7.76 \pm 0.03$ \\
\hline & 4 & $0.99 \pm 0.13$ & $0.27 \pm 0.0 .5$ & $0.18 \pm 0.01$ & $7.81 \pm 0.01$ \\
\hline & 5 & $0.98 \pm 0.12$ & $0.35 \pm 0.06$ & $0.18 \pm 0.01$ & $8.15 \pm 0.05$ \\
\hline
\end{tabular}

Table 2. Comparison of physicochemical properties of virgin coconut oil.

\begin{tabular}{|c|c|c|c|c|c|c|}
\hline Methods & $\begin{array}{l}\text { Yield } \\
(\%)\end{array}$ & $\begin{array}{c}\text { Water Content } \\
(\%)\end{array}$ & $\begin{array}{l}\text { Free Fatty Acid } \\
(\%)\end{array}$ & $\begin{array}{l}\text { Peroxide Number } \\
(\mathrm{meq} / \mathrm{kg})\end{array}$ & $\begin{array}{l}\text { Iodine Number } \\
\text { (g iodine/100 g) }\end{array}$ & Reference \\
\hline \multicolumn{7}{|l|}{ Papain } \\
\hline $\begin{array}{c}\text { Papain at } \\
\text { optimum conditions }\end{array}$ & 24.3 & 0.98 & 0.35 & 0.18 & \multirow[t]{2}{*}{8.15} & [11] \\
\hline $\begin{array}{l}\text { Papain with freezing } \\
\text { and thawing }\end{array}$ & 23 & 0.014 & 0.30 & 0.69 & & [12] \\
\hline Papain & & $0.11 \pm 0.01$ & $0.35 \pm 0.01$ & & \multirow{2}{*}{$4.26 \pm 0.05$} & [16] \\
\hline & 29.8 & 0.18 & 0.22 & & & [11] \\
\hline Peel of papaya & $12.7 \pm 1.1$ & $0.14 \pm 0.00$ & $0.17 \pm 0.00$ & $0.57 \pm 0.01$ & $8.72 \pm 0.12$ & [10] \\
\hline Seed of papaya & $12.5 \pm 0.5$ & $0.14 \pm 0.01$ & $0.15 \pm 0.01$ & $0.60 \pm 0.00$ & $8.23 \pm 0.04$ & \\
\hline \multicolumn{7}{|l|}{ Enzyme } \\
\hline Protease & & & $0.12 \pm 0.01$ & \multirow[t]{2}{*}{$0.53 \pm 0.14$} & \multirow[t]{2}{*}{$7.62 \pm 0.14$} & \multirow[t]{2}{*}{ [22] } \\
\hline Bromelain & $24.26 \pm 0.06$ & $0.34 \pm 0.01$ & $0.29 \pm 0.03$ & & & \\
\hline \multicolumn{7}{|l|}{ Fermentation } \\
\hline Natural fermentation & & $0.13 \pm 0.06$ & $0.53 \pm 0.15$ & $2.8 \pm 0.03$ & $0.91 \pm 0.03$ & [4] \\
\hline \multirow[t]{2}{*}{ Saccharomyces cerevisiae } & 12.40 & $0.04 \pm 0.01$ & $0.31 \pm 0.11$ & $0.01 \pm 0.00$ & $2.44 \pm 0.20$ & [16] \\
\hline & & $0.06 \pm 0.00$ & $0.29 \pm 0.02$ & & $4.30 \pm 0.07$ & [23] \\
\hline Bacillus licheniformis & & & $0.15 \pm 0.01$ & $0.78 \pm 0.08$ & $7.26 \pm 0.13$ & [22] \\
\hline
\end{tabular}

\subsection{Determination of Microbial Contamination}

To make sure that the produced VCO is free from microbial contamination. Table 3 shows the determination results of the total plate count in virgin coconut oil. The virgin coconut oil made enzymatic process with papain at optimum condition using the ratio of papain, volume, and temperature of the water, and the extraction stage free from microbial 
contaminant. Contamination can occur from raw materials for water and coconut, enzymes, processes, and containers. Based on the total plate count test, during the cream extraction process, separation of the virgin coconut oil by papain and the separation of virgin coconut oil did not occur with bacterial contamination.

Table 3. Determination of total plate count.

\begin{tabular}{|c|c|c|c|c|c|c|c|}
\hline \multirow{2}{*}{ Sample } & \multirow{2}{*}{ Dilution } & \multirow{2}{*}{ Medium } & \multicolumn{2}{|c|}{ Incubation } & \multicolumn{3}{|c|}{ Observation } \\
\hline & & & Temperature $\left({ }^{\circ} \mathrm{C}\right)$ & Time (Hours) & I & II & Total \\
\hline$V C O$ & $10^{-1}$ & Plate count agar & $35-37$ & $24-48$ & 0 & 0 & 0 \\
\hline$V C O$ & $10^{-2}$ & Plate count agar & $35-38$ & $24-49$ & 0 & 0 & 0 \\
\hline Control & $10^{-1}$ & Plate count agar & $35-39$ & $24-50$ & 0 & 0 & 0 \\
\hline Control & $10^{-2}$ & Plate count agar & $35-40$ & $24-51$ & 0 & 0 & 0 \\
\hline Blank & & & $35-41$ & $24-52$ & 0 & 0 & 0 \\
\hline Medium & & Plate count agar & $35-42$ & $24-53$ & 0 & 0 & 0 \\
\hline Medium + Diluent solution & & $\begin{array}{l}\text { agar-peptone } \\
\text { dilution fluid }\end{array}$ & $35-43$ & $24-54$ & 0 & 0 & 0 \\
\hline Total plate count & & $\begin{array}{c}\text { Plate count } \\
\text { agar-lactose broth }\end{array}$ & $35-44$ & $24-55$ & 0 & 0 & 0 \\
\hline
\end{tabular}

\subsection{Homogeneity and Stability Tests}

Homogeneity and stability performances are essential properties for VCO to be marketed for different products or uses. The homogeneity test was performed by examining the VCO quality parameters consisting of peroxide value and iodine for the 10 selected samples by random sampling. Table 4 shows the first criteria and the second criteria for determining mean square between (MSB) and the mean square within (MSW). A homogeneity test with a confidence interval of $95 \%$ for peroxide number and iodine number have $\mathrm{F}_{\text {test }}$ of 7.8614 and $8.0126>F_{\text {table }}=3.1789$. The virgin coconut oil produced from the enzymatic processes with papain have a homogeneity which follows the criteria of candidate in-house reference material.

Table 4. Homogeneity test of VCO.

\begin{tabular}{cccc}
\hline Parameter & Mean Square between (MSB) & Mean Square within (MSW) & F $_{\text {test }}$ \\
\hline Free fatty acid (\%) & 0.0004 & 0.0001 & 3.0146 \\
Peroxide number (meq/kg) & 0.4824 & 0.0614 & 7.8614 \\
Iodine number (mg & 0.4417 & 0.0551 & 8.0126 \\
iodine/100 g) & & & \\
\hline
\end{tabular}

For the stability test, those parameters were evaluated after six months of keeping. Usually, the higher FFA and peroxide value leads to oil instability and produce the rancidity of the product. As shown from Table 5, both samples show similar values for free fatty acid and peroxide number, suggesting the stability requirement from National Accreditation Committee with a value of $\left|\bar{x}_{i}-\bar{x}_{H M}\right|<0.3$ nIQR. Meanwhile, the stability test for iodine shows $\left|\bar{x}_{i}-\bar{x}_{H M}\right|>0.3$ nIQR. It is conclusively stated that during six months of storage, some reactions occurred to the fatty acid structure produced some fatty acid denaturation comprised for reducing stability. However, the virgin coconut oil is recommended as a candidate in-house reference material as the values fit with SNI standard and the predicted value is still in the match.

\subsection{Antibacterial Activity Test}

The antibacterial effects of $V C O$ were evaluated against Gram-positive bacteria consisting of S. aureus and P. acne, and Gram-negative bacteria of E.coli and P. aeruginosa. Some images from the tests are presented in Figure 3, and the inhibition zones (in $\mathrm{mm}$ ) are listed in Table 6. From the various concentrations of tested VCO samples. The VCO was diluted 
in dimethyl sulphoxide as the negative control in the dilution factors of $2 \mathrm{X}, 4 \mathrm{X}$, and $8 \mathrm{X}$, so the samples are denoted $V C O-2 \mathrm{X}, V C O-4 \mathrm{X}$, and $V C O-8 \mathrm{X}$, respectively, whereas $V C O$ sample is the pure sample.

Table 5. The data for stability test of free fatty acid.

\begin{tabular}{|c|c|c|c|}
\hline Parameter & Sample 1 & Sample 2 & $\overline{\mathbf{x}}$ \\
\hline \multicolumn{4}{|l|}{ Free fatty acid (\%) } \\
\hline $\mathrm{Q}_{1}$ & 0.1532 & 0.1533 & 0.1533 \\
\hline $\mathrm{Q}_{3}$ & 0.2013 & 0.1917 & 0.2003 \\
\hline IQR & 0.0482 & 0.0383 & 0.0470 \\
\hline nIQR $(0.7413$ × IQR $)$ & 0.0357 & 0.0284 & 0.0349 \\
\hline $0.3 \times \mathrm{nIQR}$ & 0.1071 & 0.0852 & 0.1046 \\
\hline$\left|\bar{x}_{i}-\bar{x}_{H M}\right|$ & 0.0544 & 0.0504 & 0.0509 \\
\hline$\left|\bar{x}_{\mathrm{i}}-\overline{\mathrm{x}}_{\mathrm{HM}}\right|<0.3 \mathrm{nIQR}$ & $0.0544<0.1071$ & $0.0504<0.0852$ & $0.0509<0.1046$ \\
\hline \multicolumn{4}{|l|}{ Peroxide number (meq/kg) } \\
\hline $\mathrm{Q}_{1}$ & 1.9956 & 2.7906 & 2.5447 \\
\hline$\hat{\mathrm{Q}}_{3}$ & 2.7972 & 3.5888 & 2.7958 \\
\hline IQR & 0.8016 & 0.7982 & 0.2511 \\
\hline nIQR $(0.7413$ × IQR) & 0.5942 & 0.5917 & 0.1862 \\
\hline $0.3 \times \mathrm{nIQR}$ & 1.7827 & 1.7750 & 0.5585 \\
\hline$\left|\bar{x}_{i}-\bar{x}_{\mathrm{HM}}\right|$ & -0.0392 & 0.9574 & 0.4591 \\
\hline$\left|\overline{\mathrm{x}}_{\mathrm{i}}-\overline{\mathrm{x}}_{\mathrm{HM}}\right|<0.3 \mathrm{nIQR}$ & $0.0392<1.7827$ & $0.9574<1.7750$ & $0.4591<0.5585$ \\
\hline \multicolumn{4}{|c|}{ Iodine number (mg iodine $/ 100 \mathrm{~g}$ ) } \\
\hline $\mathrm{Q}_{1}$ & 7.8283 & 7.9354 & 7.9173 \\
\hline$\widehat{Q}_{3}$ & 8.0926 & 8.0612 & 8.0822 \\
\hline IQR & 0.2643 & 0.1258 & 0.1649 \\
\hline nIQR $(0.7413 \times$ IQR $)$ & 0.1959 & 0.0932 & 0.1222 \\
\hline $0.3 \times \mathrm{nIQR}$ & 0.5878 & 0.2797 & 0.3667 \\
\hline$\left|\bar{x}_{i}-\bar{x}_{\mathrm{HM}}\right|$ & 1.9507 & 2.0053 & 1.9780 \\
\hline$\left|\bar{x}_{\mathrm{i}}-\overline{\mathrm{x}}_{\mathrm{HM}}\right|<0.3 \mathrm{nIQR}$ & $1.9507>0.5878$ & $2.0053>0.2797$ & $1.9780>0.3667$ \\
\hline
\end{tabular}

Table 6. Inhibition zone of antibacterial tests.

\begin{tabular}{ccccc}
\hline \multirow{2}{*}{ Tested Bacteria } & \multicolumn{5}{c}{ Inhibition Zone for Sample (mm) } \\
\cline { 2 - 5 } & VCO & VCO-2X & VCO-4X & VCO-8X \\
\hline E. coli & 18.5 & 17 & 11 & 10.5 \\
\hline S. aureus & 10 & 12.5 & 10 & 9 \\
\hline P. acne & 12 & 10.5 & 10 & 9 \\
\hline P. aeruginosa & 10 & 10 & 9 & 10 \\
\hline
\end{tabular}

Referring to the inhibition zones in S. aureus, P. acne, and P. aeruginosa bacteria test, the antibacterial activity of VCO suggests a higher activity compared to hydrolyzed VCO [24]. The inhibition zones are higher, even though the dilution factors are also higher in this research. Compared to other VCO, the activities are also higher than those reported for $S$. aureus and E. coli [14]. 

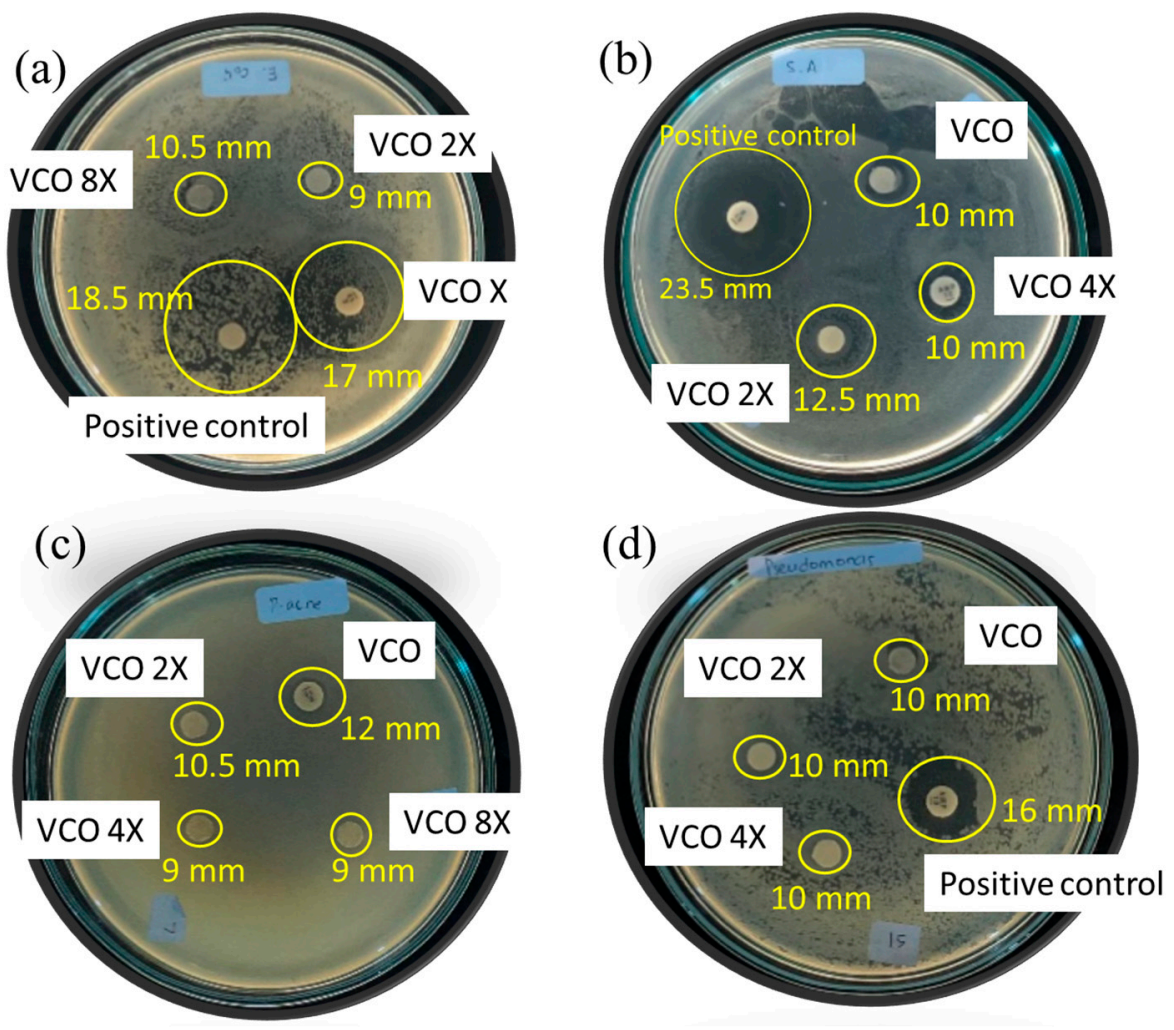

Figure 3. Some images from antibacterial activity test of VCO against (a) E. coli, (b) S. aureus, (c) P. acne, (d) P. aeruginosa.

\section{Conclusions}

Extraction of $V C O$ by using papain enzyme has been successfully conducted. The crucial factors in the extraction studied were the effect of enzymes content, water content, temperature, and extraction stage, which gave an optimum condition of $0.6 \mathrm{~g} / \mathrm{L}$ enzyme to oil ratio, the water content of $500 \mathrm{~mL} / \mathrm{g}$, and temperature $70{ }^{\circ} \mathrm{C}$. The extraction stage within the range of the $1-5$ th cycles does not have a significantly influence on extraction yield. The physicochemical character of produced $V C O$ suggests its usability as in-house reference material as the homogeneity and stability of VCO fit with the national VCO standard. Furthermore, the VCO exhibits antibacterial activity against E. coli, S. aureus, P. acnes, and P. aeruginosa.

Author Contributions: Conceptualization, Y.R. and I.F.; methodology, Y.R.; software, I.F.; validation, Y.R., H.H. and I.F.; formal analysis, Y.R. and A.R.W.; investigation, A.R.W.; resources, A.R.W.; data curation, H.H.; writing—original draft preparation, Y.R. and H.H.; writing-review and editing, I.F.; visualization, Y.R.; supervision, I.F.; project administration, A.R.W.; funding acquisition, Y.R. All authors have read and agreed to the published version of the manuscript.

Funding: This research was funded by Chemistry Department Faculty Mathematics and Natural Sciences Universitas Islam Indonesia.

Acknowledgments: This study supported by Chemistry Department Faculty Mathematics and Natural Sciences Universitas Islam Indonesia. The authors gratefully acknowledged the support.

Conflicts of Interest: The authors declare no conflict of interest regarding to the submission.

\section{References}

1. Hanjaya, C.; Pranata, F.S.; Swasti, Y.R. Quality of Virgin Coconut Oil with Addition of Peppermint Oil. agriTECH 2020, 40, 215. [CrossRef]

2. Anzaku, A.A. Antimicrobial Activity of Coconut Oil and its Derivative (Lauric Acid) on Some Selected Clinical Isolates. Int. J. Med. Sci. Clin. Invent. 2017, 4, 3173-3177. [CrossRef] 
3. Nguyen, V.T.A.; Le, T.D.; Phan, H.N.; Tran, L.B. Antibacterial Activity of Free Fatty Acids from Hydrolyzed Virgin Coconut Oil Using Lipase from Candida rugosa. J. Lipids 2017, 2017, 1-7. [CrossRef]

4. Ghani, N.A.A.; Channip, A.A.; Chok Hwee Hwa, P.; Ja'afar, F.; Yasin, H.M.; Usman, A. Physicochemical properties, antioxidant capacities, and metal contents of virgin coconut oil produced by wet and dry processes. Food Sci. Nutr. 2018, 6, 1298-1306. [CrossRef] [PubMed]

5. Sundrasegaran, S.; Mah, S.H. Extraction Methods of Virgin Coconut Oil and Palm-pressed Mesocarp Oil and their Phytonutrients. eFood 2020, 1, 381. [CrossRef]

6. Agarwal, R.K. Extraction Processes of Virgin Coconut Oil. MOJ Food Process. Technol. 2017, 4, 54-56. [CrossRef]

7. Arslan, A.; Rancke-Madsen, A.; Brask, J. Enzymatic synthesis of estolides from castor oil. Catalysts 2020, 10, 835. [CrossRef]

8. Díaz-Suárez, P.; Rosales-Quintero, A.; Fernandez-Lafuente, R.; Pola-Sánchez, E.; Hernández-Cruz, M.C.; Ovando-Chacón, S.L.; Rodrigues, R.C.; Tacias-Pascacio, V.G. Aqueous enzymatic extraction of Ricinus communis seeds oil using Viscozyme L. Ind. Crops Prod. 2021, 170, 113811. [CrossRef]

9. Amri, E.; Mamboya, F. Papain, a plant enzyme of biological importance: A review. Am. J. Biochem. Biotechnol. 2012, 8, 99-104. [CrossRef]

10. Diyah, N.W.; Purwanto; Susanti, Y.; Dewi, Y.K. Pembuatan Minyak Kelapa secara Enzimatis dengan memanfaatkan Kulit Buah dan Biji Pepaya serta Analisis Sifat Fisikokimianya. Berk. Penelit. Hayati 2010, 15, 181-185. [CrossRef]

11. Rukman, W.Y.; Safitri, D.; Fadhilah, N.; Wajdi, M. Papain-induced enzyme source to the quality of virgin coconut oil. Int. J. Multidiciplinary Res. Dev. 2018, 5, 57-59.

12. Raharja, S. dan Dwiyuni, M. Study on Physico-Chemical Characteristics of Virgin Coconut Oil (VCO) Made by Coconut Milk Cream Freezing Method. J. Tek. Ind. Pertan. 2005, 18, 71-78.

13. Bisht, T.S.; Sharma, S.K.; Sati, R.C.; Rao, V.K.; Yadav, V.K.; DIxit, A.K.; Sharma, A.K.; Chopra, C.S. Improvement of efficiency of oil extraction from wild apricot kernels by using enzymes. J. Food Sci. Technol. 2015, 52, 1543-1551. [CrossRef]

14. Loung, F.S.; Silalahi, J.; Suryanto, D. Antibacterial activity of enzymatic hydrolyzed of virgin coconut oil and palm kernel oil against staphylococcus aureus, Salmonella thypi and Escherichia coli. Int. J. PharmTech Res. 2014, 6, 628-633.

15. Effendi, A.M.; Pratjojo, W.; Sumarni, W. Optimalisasi Penggunaan Enzim Bromelin Dari Sari Bonggol Nanas Dalam Pembuatan Minyak Kelapa. Indones. J. Chem. Sci. 2012, 1, 1-6.

16. Rohyami, Y.; Anjani, R.D.; Purwanti, N.P. The influence of Saccharomyces cerevisiae enzyme ratio on preparation virgin coconut oil for candidate in-house reference materials. AIP Conf. Proc. 2017, 1823, 020086. [CrossRef]

17. Idrus, N.F.M.; Febrianto, N.A.; Zzaman, W.; Cuang, T.E.; Yang, T.A. Optimization of the aqueous extraction of virgin coconut oil by response surface methodology. Food Sci. Technol. Res. 2013, 19, 729-737. [CrossRef]

18. Thepakorn, T.; Kanasawud, P.; Halling, P.J. Activity of immobilized papain dehydrated by n-propanol in low-water media. Biotechnol. Lett. 2004, 40, 133-136. [CrossRef]

19. Tansakul, A.; Chaisawang, P. Thermophysical properties of coconut milk. J. Food Eng. 2006, 73, 276-280. [CrossRef]

20. Raghavendra, S.N.; Raghavarao, K.S.M.S. Effect of different treatments for the destabilization of coconut milk emulsion. J. Food Eng. 2010, 97, 341-347. [CrossRef]

21. Asiah, N.; Astuti, R.M.; Cempaka, L.; Setiani, R. Physical and Chemical Characteristic of Virgin Coconut Oil under Mix Culture Fermentation Technique. J. Phys. Conf. Ser. 2019, 1364, 012009. [CrossRef]

22. Prapun, R.; Cheetangdee, N.; Udomrati, S. Characterization of virgin coconut oil (VCO) recovered by different techniques and fruit maturities. Int. Food Res. J. 2016, 23, 2117-2124.

23. Mansor, T.S.T.; Che Man, Y.B.; Shuhaimi, M.; Abdul Afiq, M.J.; Ku Nurul, F.K.M. Physicochemical properties of virgin coconut oil extracted from different processing methods. Int. Food Res. J. 2012, 19, 837-845.

24. Silalahi, J.; Permata, Y.M.; Putra, E.D. Antibacterial activity of hydrolyzed virgin coconut oil. Asian J. Pharm. Clin. Res. 2014, 7, 90-94. 